\title{
FIZIKALNI MODEL FORMIRANJA GRANIČNOG SLOJA
}

\section{PHYSICAL MODEL OF FORMING THE BOUNDARY LAYER}

\author{
Mauro Pamić*, Elvis Žic ${ }^{*}$, Ignacijo Biluš ${ }^{* *}$, Luka Lešnik**
}

\begin{abstract}
Sažetak
U radu se razmatraju temeljna načela za formiranje graničnog sloja kod ravninskih (2D) i prostornih (3D) objekata te je dat opis načina njegova formiranja pomoću fizikalnih modela HM 133 i HM 152 (tvrtke GUNT), koji su sastavni dio hidrotehničkog laboratorija Građevinskog fakulteta Sveučilišta u Rijeci. U prvom dijelu rada definirane su osnove gibanja tekućine putem Lagrangeovog i Eulerovog pristupa. Kroz tekstualne formulacije i grafičke prikaze objašnjeno je značenje trajektorija, strujnica, vektora brzina i ubrzanja, kao i njihova povezanost. Također je opisan pojam kutne deformacije koju trpi čestica tekućine uslijed gibanja. U nastavku rada dat je opis osnovnih teorijskih pretpostavki o formiranju graničnog sloja te triju vrsta tečenja obzirom na njegovo formiranje. Tu je i dio koji upućuje na važnost hrapavosti podloge i gradijenta tlaka na formiranje graničnog sloja. Zatim su prikazane zakonitosti utvrđene za sustave otvorenih kanala jer njima odgovaraju uvjeti na korištenim fizikalnim modelima. Nadalje su opisani principi rada dva navedena fizikalna modela, način pripreme samih eksperimentanih ispitivanja te je provedena analiza opstrujavanja fluida na pojedinim ravninskim, 2D objektima (kružnog, pravokutnog $i$ aerofilnog oblika) $i$ prostornim, 3D objektima (cilindričnog $i$ aerodinamičkog oblika).
\end{abstract}

Ključne riječi: gibanje fluida, granični sloj, opstrujavanje, fizikalni model, HM 133 i HM 152

\footnotetext{
Abstract

The paper deals with the basic principles of forming the boundary layer in linear (2D) and spatial (3D) objects, along with the description and manner of their forming using

* Građevinski fakultet Sveučilišta u Rijeci, Radmile Matejčić 3, 51000 Rijeka

E-mail: \{mauro.pamic@student.uniri.hr; elvis.zic@uniri.hr\}

${ }^{* *}$ Institut za energetsko, procesno i okolišno inženjerstvo, Tehnički fakultet Sveučilišta u

Mariboru, Smetanova ulica 17, 2000 Maribor

E-mail: \{ignacijo.bilus@um.si; luka.lesnik@um.si\}
} 
physical models GUNT HM 133 and GUNT HM 152, which are an integral part of the hydro-technical laboratory of the Faculty of Civil Engineering, University in Rijeka. Firstly, the paper defines motion of liquid basics with Lagrange and Euler approach. The meaning of trajectories, streamlines, velocity vectors and acceleration, as well as their interdependence, were explained using textual formulations and graphic displays. The concept of angular deformities, suffered by particles of fluid due to movement, were also described. Furthermore, the paper describes the basic theoretical assumptions regarding formation of a boundary layer and three types of flow due to their formation. A part of paper also points to the importance of surface roughness and pressure gradient regarding the formation of the boundary layer. The legalitie, deremined for open channel systems, are also shown, because they correspond to the conditions of the applied physical modes. The paper describes the principles of work for the two stated physical models, the manner of preparing the experimental tests, and the conducted hydrodynamic analysis of fluid circulation on certain linear 2D structures (of circular, rectangular and aerofil shape) and spatial $3 D$ structures (of cylindrical and aerodynamic shape).

Key words: fluid motion, boundary layer, fluid flow around the body, physical model, HM 133 and HM 152

\section{Uvod}

Granični sloj gotovo je neizostavna pojava kod nailaska vodenog toka na prepreku, kao i kod ohrapavljene podloge po kojoj fluid struji. Za opis takvih pojava moguća su dva polazišta, poznata kao Lagrangeov i Eulerov pristup, kojima se pretpostavlja način gibanja fluida [1]. Kod Lagrangeovog pristupa se za promatrani volumen $V$ fluida prati gibanje relativno malog dijela tekućine (čestice). S obzirom na djelovanja kojima je čestica izložena te ograničenja definirana samim fluidom, moguće je pratiti strujanje fluida kao cjeline. Stoga je potrebno da se za svaku promatranu česticu definira njen položaj koji će ovisiti o koordinatama kontrolnog volumena u kojem se nalazi. Isto tako, čestica mora biti definirana vremenom, jer se promjenom

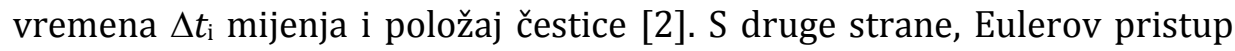
polazi od toga da se za promatrani volumen $V$ fluida više ne prati gibanje pojedinih čestica tekućine, već se odabranu promatranu točku prostora nastoji fiksirati u vremenu i prostoru. U toj točki prostora se zatim promatra promjena svih fizikalnih veličina strujanja [2].

Prostor za koji se provodi analiza tečenja naziva se strujno polje. Ono je opisano nizom manjih polja koja su definirana pripadajućim fizikalnim veličinama (polje tlakova, polje brzina, polje ubrzanja i sl.). Polje brzine je vektorsko polje, što znači da svaki dio tekućine ima različitu brzinu po intenzitetu i smjeru. Ukoliko je poznat i vektor položaja odabranog dijela tekućine s obzirom na ishodište referentnog koordinatnog sustava, polje brzina bit će određeno za svaku točku tekućine. Ukoliko se fizikalne veličine 
strujnog polja ne mijenjaju tijekom vremena niti u prostoru, riječ je o stacionarnom strujanju $(\vec{v}=\vec{v}(x, y, z))$. U suprotnom govorimo o nestacionarnom strujanju $(\vec{v}=\vec{v}(x, y, z, t))$. Brzina se definira kao prevaljeni put $\mathrm{d} s \mathrm{u}$ vremenu $\mathrm{d} t$. Ukoliko se taj izraz integrira po vremenu, dobit će se trajektorija, odnosno putanja koju određena čestica fluida prođe tijekom tečenja [1]. Ako se za neko strujno polje u svakoj točki definira vektor brzine $\vec{v}$ u danom trenutku $t$, iscrtanu liniju, koja spaja točke tako da u svakoj od njih vektor brzine tangira, nazivamo strujnicom. Strujnice se ne mogu sjeći jer se čestica fluida u isto vrijeme ne može kretati u više smjerova $[3,4]$. Budući da kod stacionarnog tečenja ne dolazi do promjena fizikalnih veličina, trajektorije i strujnice će se preklapati. To nije tako u uvjetima nestacionarnog tečenja. Kada veći broj strujnica, koje su pozicionirane jedna do druge, presijecaju površinu $A$, takav skup strujnica nazivamo strujno vlakno. Kako se brzina, tlak ili bilo koja druga fizikalna veličina jednoliko raspoređuju kroz presjeke strujnog vlakna, problem se predstavlja kao jednodimenzionalni [1].

Promjena brzine $\vec{v}$ u vremenu $t$, odnosno ubrzanje $\vec{a}$, još je jedna u nizu fizikalnih veličina od velikog značaja za područje hidrodinamike. Ubrzanje je, kao i brzina, vektorska veličina koja je definirana promjenom položaja vektora $\vec{v}$ u određenom trenutku $t$. Za taj trenutak i taj položaj prati se ubrzanje ili usporenje čestice fluida uzduž strujnica, odnosno trajektorija ds. Ubrzanje sadrži komponentu tangencijalnog ubrzanja $\vec{a}_{\mathrm{t}}$ i komponentu centripetalnog ubrzanja $\vec{a}_{\text {n }}$ tako što se tangencijalno ubrzanje javlja kao tangenta na strujnicu, dok je komponenta centripetalnog ubrzanja normala na strujnicu [1].

Osim promjene položaja, čestica fluida tijekom svog tečenja unutar strujnog polja trpi i deformaciju. Deformacija se kod čestice očituje u promjeni oblika na način da se mijenjaju vrijednosti početnih duljina stranica, kao i kutovi između njih. Ukoliko se želi dobiti vrijednost promjene oblika, čestica se mora gibati od jedne do druge položajne točke unutar strujnog polja za neko vrijeme $t$ [1]. U radu [5] su detaljno dane formulacije i opis mogućih deformacija čestica fluida.

\section{Dinamika realne tekućine}

Zahvaljujući radu francuskog inženjera Osbornea Reynoldsa i pokusima koje je proveo, danas razlikujemo 3 vrste strujanja koja opisuju dinamiku realne tekućine. Za zatvorene cijevne sustave, Reynolds je definirao i objasnio načine strujanja i temeljne razlike između pojedinih strujanja. Upuštajući obojenu tekućinu u cijevi, usporedno promjeni brzine strujanja tekućine mijenjao se i način strujanja obojenog traga upuštene tekućine. Time je definirao postojanje laminarnog, prijelaznog i turbulentnog 
strujanja. Kod sva tri oblika strujanja, trenje između graničnih površina i tekućine savladava se pomoću energije tlaka tako što se oduzima energija strujanja tekućine. Na taj se način zadržavaju karakteristični profili brzina $[3,4]$.

Laminarno strujanje karakteriziraju vrlo male brzine. Budući da su brzine male, gibanje vlakna je u pravcu. Točnije, strujanje možemo opisati kao snop koncentričnih tankostjenih cjevčica „lamina“ za koje vrijedi, gledajući od ruba cijevi prema središtu, da im se brzina strujanja povećava, a najveću vrijednost doseže u središtu cijevi. Srednja brzina u cijevi može se proračunati na temelju izraza $\bar{v}=0,5^{*} v_{\max }$, dok raspodjela brzina poprima oblik paraboloida [3,4]. Također, razlikujemo potencijalno i vrtložno laminarno strujanje. Za postojeće profile brzina, kod potencijalnog strujanja ne dolazi do pojave vrtloga. Kod vrtložnog laminarnog strujanja, između dva sloja tekućine pri različitim brzinama dolazi do pojave pravilnih i stabilnih elementarnih vrtloga [4]. Navier-Stokesove diferencijalne jednadžbe u potpunosti opisuju laminarno strujanje gdje je:

$$
\frac{d \vec{v}}{d t}=\vec{f}-\frac{1}{\rho} \operatorname{gradp}+v \Delta \vec{v}+\frac{1}{3} \text { vgraddiv } \vec{v}
$$

izraz za vektorski oblik gibanja. Posljednja dva člana na desnoj strani određuju utjecaj sila viskoznosti. Ono što razlikuje Navier-Stokesove jednadžbe od Eulerovih jest član $\Delta \vec{v}$. Strujanje, čije su brzine vrijednosno između laminarnog i turbulentnog, naziva se prijelazno strujanje. Ono što razlikuje prijelazno strujanje od laminarnog je valovito gibanje nasuprot gibanja u pravcu, dok vlakno zadržava kontinuitet [3]. Sa sve većim rastom brzina strujanja vlakno počinje gubiti svoj kontinuitet te se na određenoj udaljenosti raspada. Raspadnuto vlakno se proteže duž cijelog presjeka cijevi, što dovodi do miješanja brzih i sporih čestica tekućine pa se tako brzina na stjenkama povećava, dok u središtu presjeka ona opada. Takvo strujanje naziva se turbulentno strujanje za koje raspodjela brzina poprima oblik rotacijske logaritamske krivulje, dok srednja brzina strujanja poprima izraz $\vec{v}=(0,75 \div 0,85)^{*} v_{\max }$ [6]. Kod turbulentnog strujanja ukupnu brzinu čine njena srednja vrijednost $\vec{v}$ i tzv. oscilacija, odnosno odstupanje od njene srednje vrijednosti $\vec{v}^{\prime}$ u nekom vremenskom intervalu $T$ mjerenja [5]. Kao dodatne mjere uvode se intenzitet turbulencije $\left(I=\frac{\sqrt{\bar{v}^{-2}}}{\bar{v}}\right)$, koeficijent korelacije te učestalost oscilacija. Koeficijent korelacije služi kao pokazatelj međusobne povezanosti brzina trenutnih odstupanja. Nju povezujemo sa slučajem turbulentnosti dva djelića tekućine koja zbog različitih oscilacija u istu točku stižu u različitim vremenskim razmacima [6]. Učestalost oscilacija, kao treća uvedena mjera, važna je zato što je potrebno jasno odijeliti dvije vrste oscilacija koje se javljaju pri turbulentnom strujanju. Riječ je o makroskopskim i mikroskopskim oscilacijama. Ono što dijeli jednu 
od druge jesu amplituda i frekvencija osciliranja. Pri makroskopskim oscilacijama amplitude su vrlo velike, što za posljedicu ima nisku frekvenciju osciliranja. Za mikroskopske oscilacije slučaj je upravo suprotan. Treba reći da su mikroskopske oscilacije sveprisutne i da uslijed visoke frekvencije dolazi do preraspodijele iz mehaničke u toplinsku energiju [6].

\subsection{Granični sloj na ravnoj ploči}

Svaki granični sloj koji se formira uslijed strujanja neposredno uz podlogu sadrži gradijente brzine zato što uz samu podlogu dio tekućine zaostaje uslijed lijepljenja za istu (utjecaj hrapavosti), dok se tok u središtu presjeka ne mijenja. Najbolji primjer toga je razvoj graničnog sloja na ravnoj ploči, koji se počinje javljati već na njenom samom početku. Neovisno o jačini turbulencije tekućine prije nailaska na ploču, na početku ploče će se uvijek razvijati laminarni granični sloj. Budući da je strujanje jednoliko, doći će do postepenog odmicanja strujnica od ploče, odnosno, uslijed smanjenja brzine poremećeni tok će se početi širiti. Kad Reynoldsov broj Re dosegne kritičnu vrijednost, tj. kada se sloj proširi, laminarni tok postaje sve uži i počinje se razvijati turbulencija (Slika 1) [3,6].

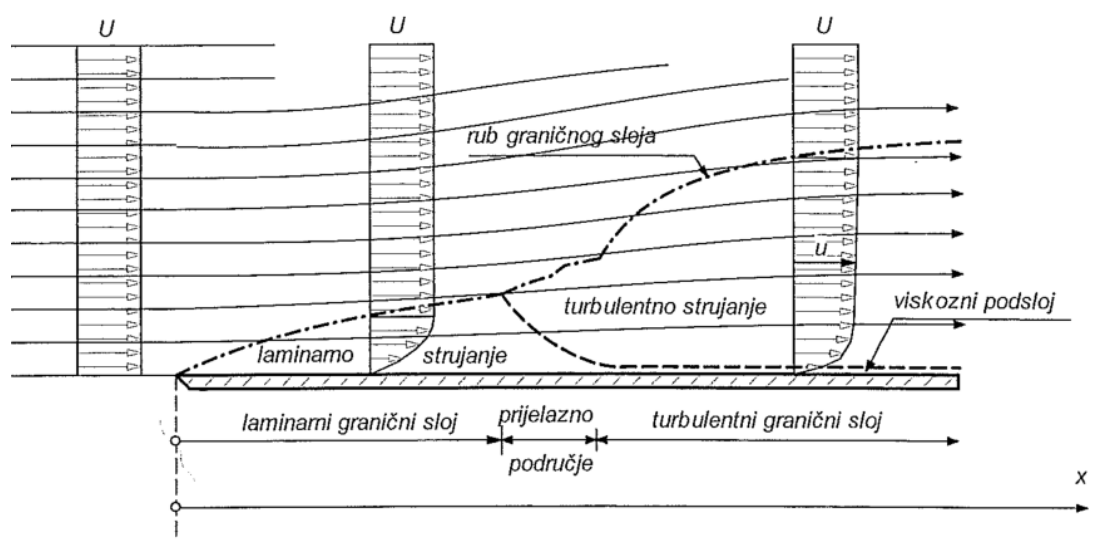

Slika 1. Razvoj graničnog sloja na ravnoj ploči [3]

Debljina graničnog sloja definirana je udaljenošću od ploče, gdje je brzina toka $v_{x}$ manja za $1 \%$ u odnosu na neporemećenu brzinu toka $U[3,6]$. Osim debljine graničnog sloja postoje još i debljina istisnuća i debljina količine gibanja kao geometrijske karakteristike koje utječu na granični sloj. Debljinom istisnuća ili debljinom izgubljenog protoka $\delta_{1}$ nastoji se ostvariti protok koji je jednak stvarnom protoku na način da pomičemo nepokretnu površinu prema osnovnoj struji sve dok se protoci ne ujednače (Slika 2). Unutar te debljine strujanje je poremećeno [3], a sama debljina izražena je kako slijedi: 


$$
U \delta_{1}=\int_{0}^{\delta}\left(U-v_{x}\right) d y
$$

Kroz debljinu izgubljene količine gibanja $\delta_{2}$ nastoji se izjednačiti količina gibanja koja se izgubila uslijed opadanja brzine toka u graničnom sloju te količina gibanja unutar graničnog sloja konstantne brzine [6], iz čega slijedi:

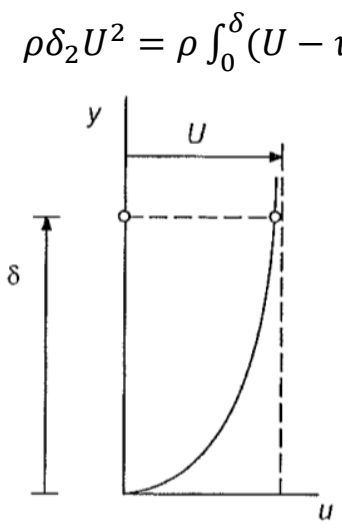

a) normalna debljina

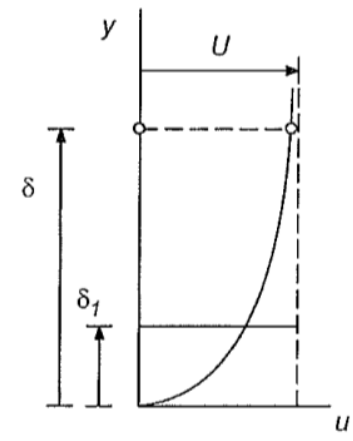

b) debljina istisnuća

$$
\delta_{2}=\int_{0}^{\delta} \frac{v_{x}}{U}\left(1-\frac{v_{x}}{U}\right) d y
$$

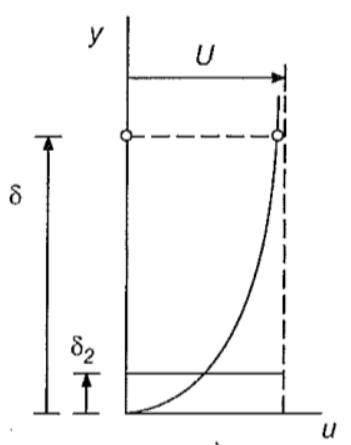

c) debljina količine gibanja

Slika 2. Debljine dijelova graničnog sloja [3]

Trenje po podlozi u graničnom sloju javlja se kao posljedica lijepljenja fluida koji teče na podlozi, a njegova se vrijednost očituje u graničnom sloju, odnosno njegovom razvoju. Što je veći razvoj graničnog sloja, to će i otpor trenja biti veći. Kako bi se odredila točna vrijednost trenja potrebno je uravnotežiti količine gibanja. Ukoliko se promatra kontrolni volumen za dva bliska presjeka sa njihovim graničnim slojem i dijelom koji obuhvaća strujanje koje je neporemećeno, moguće je dobiti trenje na ploči čiji će koeficijent trenja $c_{f}$ varirati ovisno o razvitku graničnog sloja [3]. Koeficijent se određuje prema izrazu $c_{f}=2 \frac{\mathrm{d} \delta_{2}}{\mathrm{dx}}$ na temelju zakona o održanju količine gibanja kontrolnog volumena i detaljno je opisan u radu [5].

\subsection{Hidrodinamički otpori u kanalima}

Slično kao i na ravnoj ploči, granični se sloj razvija i u kanalima. Jedini problem njegova definiranja jest oblik poprečnog presjeka kanala. Problem se javlja zato što svaki kanal ima sebi svojstven oblik i promjenjiv poprečni presjek, čime se mijenjaju uvjeti toka. Otpor trenja kao sila, osim što se veže za podlogu, također se javlja i kod tijela uronjenih u tekućinu i zajedno sa otporom oblika uronjenog tijela predstavlja hidrodinamičke otpore. Dok je otpor trenja definiran brzinom toka, otpor oblika je određen i tlakom oko uronjenog tijela, a on će ovisiti o geometrijskim karakteristikama tijela, kao i samoj veličini. Vrlo je čest slučaj da pri manjim brzinama ukupnu silu otpora većim dijelom čini otpor trenja, dok je za veće brzine znatno izražen 
otpor oblika. Ukupna sila otpora jednaka je zbroju otpora trenja i otpora oblika [4]. Često se vrtložni trag prihvaća kao mjera otpora jer se njegovim odnosom uzdužnog i poprečnog odmaka od uronjenog tijela definira koeficijent otpora $C_{D}$ koji je ovisan o Reynoldsovom broju $R e$ i geometriji uronjenog tijela (Tablica 1).

Tablica 1. Koeficijenti otpora pojedinih tijela pri opstrujavanju fluida [5]

\begin{tabular}{|c|c|c|c|}
\hline Tijelo - struji s lijeva na desno & $l / d$ & $R e=v d / v$ & $C D$ \\
\hline \multirow{6}{*}{$\begin{array}{l}\text { l. Kružni cilindar - os normalna na } \\
\text { struju }\end{array}$} & l & $10^{5}$ & 0,63 \\
\hline & 5 & & 0,74 \\
\hline & 20 & & 0,90 \\
\hline & $\infty$ & & 1,20 \\
\hline & 5 & $>5^{*} 10^{5}$ & 0,35 \\
\hline & $\infty$ & & 0,33 \\
\hline \multirow{5}{*}{ 2. Kružni cilindar - os paralelna struji } & 0 & \multirow{5}{*}{$>10^{3}$} & 1,12 \\
\hline & 1 & & 0,91 \\
\hline & 2 & & 0,85 \\
\hline & 4 & & 0,87 \\
\hline & 7 & & 0,99 \\
\hline \multirow{4}{*}{$\begin{array}{ll} & \\
3 . \text { Eliptični } & (2: 1) \\
& (4: 1) \\
& (8: 1)\end{array}$} & & \multirow{4}{*}{$\begin{array}{c}4 * 10^{4} \\
10^{5} \\
2,5^{*} 10^{4} \text { do } 10^{5} \\
2,5^{*} 10^{4} \\
2 * 10^{5}\end{array}$} & 0,6 \\
\hline & & & 0,46 \\
\hline & & & 0,32 \\
\hline & & & 0,29 \\
\hline 4. Aeroprofil (1:3) & $\infty$ & $>4 * 10^{4}$ & 0.07 \\
\hline \multirow{4}{*}{$\begin{array}{l}\text { 5. Pravokutna ploča normalna na } \\
\text { struju gdje je } l=\text { dužina, } d=\text { širina }\end{array}$} & 1 & \multirow{4}{*}{$>10^{3}$} & 1,16 \\
\hline & 5 & & 1,20 \\
\hline & 20 & & 1,50 \\
\hline & $\infty$ & & 1,90 \\
\hline \multirow[t]{3}{*}{ 6. Kvadratna prizma } & & & \\
\hline & & $3,5 * 10^{4}$ & 2,0 \\
\hline & & $10^{4}$ do $10^{5}$ & 1,6 \\
\hline \multirow{6}{*}{$\begin{array}{l}\text { 7. Trostrana prizma } \\
120^{\circ}\end{array}$} & & \multirow{4}{*}{$>10^{4}$} & 2,0 \\
\hline & & & 1,72 \\
\hline & & & 2,20 \\
\hline & & & 1,39 \\
\hline & & \multirow{2}{*}{$>10^{5}$} & 1,80 \\
\hline & & & 1,0 \\
\hline \multirow[t]{3}{*}{ 8. Poluloptasta ljuska } & & & \\
\hline & & $>10^{3}$ & 1,33 \\
\hline & & $10^{3}$ do $10^{5}$ & 0,4 \\
\hline 9. Disk normalan u struji & & $>10^{3}$ & 1,12 \\
\hline
\end{tabular}


Ono što karakterizira turbulentni granični sloj je izražena turbulentna zona s vrtlozima putem kojih se ostvaruje izmjena količine gibanja. To područje naziva se i turbulentnom jezgrom, a definiraju ga prevladavajuće sile inercije u odnosu na sile viskoznosti. Tek na manjem dijelu graničnog sloja, točnije, u viskoznom podsloju, sile viskoznosti dolaze do izražaja te on, zajedno sa područjem prijelaza i zidnom turbulencijom, čini unutarnju zonu graničnog sloja [6]. Upravo je zidna turbulencija područje unutar graničnog sloja u kojem se vrijednosti sila viskoznosti i turbulencije donekle izjednačavaju te nastupa izmjena turbulentnih virova. Što je turbulentno područje više izraženo, to će brzina u podsloju biti veća, što za rezultat ima i veća naprezanja na zidu.

\subsection{Svojstva graničnog sloja sa gradijentom tlaka}

Pri nejednolikom strujanju, osim brzine, na sam razvitak graničnog sloja također značajno utječe i gradijent tlaka. Pri ubrzavajućem strujanju, zahvaljujući porastu brzine (a, sukladno s time, i padu tlaka), uslijed jakog naleta uzdužne struje dolazi do nemogućnosti zadržavanja vrtloga nastalih na graničnom sloju. Stoga se granični sloj ne širi i ostaje vrlo tanak. Kod usporavajućih strujanja efekt je upravo suprotan [6].

Odvajanje graničnog sloja karakteristika je usporavajućih strujanja, a nastupa uslijed kontinuiranog širenja graničnog sloja. Naime, pri neprestanom širenju graničnog sloja, tangente na brzine sve više teže okomitosti prema podlozi, a usporedno s time se trenje po ploči smanjuje sve do stanja njegova nepostojanja. Nepostojanje trenja, odnosno vrijednost trenja jednaka 0 , nastat će u trenutku kada tangenta bude okomita na ploču. Kako tlak sve više raste, stvara se struja koja se vraća te, u točki okomite tangente te odvaja granični sloj od podloge (točka separacije). Bilo da se radi o ravnoj ili zakrivljenoj podlozi, ključnu ulogu u odvajanju graničnog sloja odigravaju pad brzine toka i porast tlaka, a odvajanje se događa na mjestu gdje je gibanje zaustavljeno $[3,6]$.

Svako tijelo koje je uronjeno u tekućinu i pritom opstrujavano tom istom tekućinom podvrgnuto je djelovanju naprezanja $\tau$. Naprezanje koje djeluje na tijelo u smjeru toka jest tlačno naprezanje. Ako se to naprezanje uvede pod integral određen poprečnim presjekom uronjenog tijela $A$, kao rezultat se dobiva vrijednost sile otpora tijela $F_{\mathrm{x}}$ :

$$
F_{X}=\int_{A}^{0}(-p \cos \Theta) d A+\int_{A}^{0}(\tau \sin \Theta) d A
$$

pri čemu prvi član predstavlja silu otpora oblika, a drugi silu otpora trenja [1]. Oblik uronjenog tijela u krajnosti utječe na raspodjelu tlaka $p$ koji se manifestira preko sile otpora, što ukazuje na važnost izračuna vrijednosti same sile. Sila otpora će biti jednaka nuli iznimno kod „idealne tekućine“ 
gdje ne dolazi do pojave graničnog sloja. U svim ostalim slučajevima sila otpora se može proračunati preko izraza:

$$
F_{x}=C_{x} \rho A_{p} \frac{v o^{2}}{2}
$$

gdje je $C_{x}$ bezdimenzionalni koeficijent otpora tijela, $\rho$ gustoća tekućine, a $A_{p}$ površina ortogonalne projekcije tijela na vertikalnu ravninu okomitu na strujnice [1]. Sila otpora $F_{x}$, gustoća tekućine $\rho$, brzina opstrujavanja $v_{0}$ kao i površina presjeka tijela $A_{p}$ vrlo su lako odredive, što za rezultat ima već unaprijed određene vrijednosti koeficijenata otpora $C_{X}$, bilo da je riječ o 2D ili 3D oblicima tijela. U radu [5] su navedene vrijednosti koeficijenata otpora $C_{x}$ u funkciji Reynoldsovog broja $R e$ za 2D i 3D modele tijela prema autorima Robinsonu i Croveu (1993.).

\section{Korišteni fizikalni modeli}

Za potrebe fizičkog ispitivanja graničnog sloja poslužila su dva fizikalna modela (HM 133 i HM 152) firme GUNT, uspostavljena u sklopu hidrotehničkog laboratorija Građevinskog fakulteta Sveučilišta u Rijeci. Budući da se hidrauličke zakonitosti ne baziraju samo na teorijskoj osnovi, ovim se pokusima nastojala potkrijepiti njihova valjanost kroz fizikalne procese. Fizikalni modeli su izrađeni u prigodnom mjerilu te na temelju sličnosti sa proučavanom hidrauličkom pojavom omogućuju zorni uvid u fenomene pojave. Budući da je model znatno manji i definiran mjerilom, pomoću faktora mjerila po Froudeovom i Reynoldsovom zakonu sličnosti moguće je za svaku od fizikalnih veličina dobiti njenu stvarnu (realnu) vrijednost. Pomoću modela se nastojalo dobiti uvid u formiranje graničnih slojeva s obzirom na različite oblike 2D ili 3D tijela koje se postavlja unutar radne plohe (sekcije) fizikalnog modela.

Prvi fizikalni model koji je korišten je fizikalni model HM 133. Preko napajanja električnom energijom model proizvodi mjehuriće kojima se prikazuju strujnice (u konačnici snop strujnica - linijskih ili krivolinijskih formiranje turbulencija). Preko niza postavljenih tijela omogućen je prikaz velikog broja opstrujavanja fluida oko istih, a mnoge se od tih pojava mogu pojaviti u svakodnevnim hidrodinamičkim procesima. Zahvaljujući svom pravokutnom obliku presjeka kanala i posebnom obliku osvjetljenja može se vrlo dobro vizualizirati tip strujanja pri odgovarajućim vrijednostima protoka $Q$, odnosno brzine $v$.

Drugi model koji se korisito za ispitivanje je fizikalni model HM 152. Specifičnost ovog modela je rešetkasta ploča kroz koju teče/cirkulira voda s lijeva na desno (gornji i donji spremnik sa ugrađenom pumpom), pri čemu se usporedno upušta i posebna tinktura za formiranje strujnica, odnosno 
strujnog polja. Dotok vode regulira se preko dovodnog ventila, dok se tinktura (medij) u nju upušta putem 19 mlaznica (proizvoljno odabranih u radu). Na ploču je moguće položiti 2D tijela raznovrsnih oblika, dok se sustavom ventila $\mathrm{u}$ toku mogu izazvati umjetne pojave poput izvora ili ponora. Primjenom različitih kombinacija na modelu moguće je vidjeti promjene u toku uslijed opstrujavanja fluida oko različitih oblika tijela pri formiranju izvora ili ponora te na taj način dobiti jasnu sliku strujnog polja s potrebnim strujnicama i ekvipotencijalama.

\subsection{Fizikalni model HM 133}

Fizikalni model HM 133 sastoji se od protočnog kanala ugrađenog u polistirenski spremnik [7]. Crpka, postavljena u kućište ispod polistirenskog spremnika, osigurava kontinuiranu cirkulaciju vode. Brzina protoka se prilagođava pomoću crpke koja ima mogućnost regulacije brzine okretnog kola. Kako bi se protok na ulaznom dijelu spremnika usporio, koriste se staklene kuglice, dok se reguliranje razine vode na području mjerne sekcije postiže preko pregrade s prorezima poput „češlja“. Za vizualizaciju toka koriste se mali vodikovi mjehurići koji se stvaraju preko platinaste žice elektrolizom. Platinasta žica je spojena s negativnim polom na istosmjerni napon i djeluje kao katoda, dok ploča od nehrđajućeg čelika koja je uronjena u vodu djeluje kao anoda (Slika 3 i 4). Za povećanje vodljivosti tekućine i gustoće mjehurića dodaje se natrijev sulfat dekahidrat $\left(\mathrm{Na}_{2} \mathrm{SO}_{4} * 10 \mathrm{H}_{2} \mathrm{O}\right.$, Glauberova sol, tenardit). Razvoj mjehurića može se kontrolirati i regulirati preko kontrolne ploče (regulatora mjehurića vodika), odnosno povećanjem jakosti struje preko anode i katode. Kako bi se mjehurići vodika jasnije vidjeli, mjerna sekcija za vizualizaciju toka (radna ploha) je osvijetljena jakim bijelim svijetlom s obje bočne strane. Radna ploha je opremljena prozorom od pleksiglasa dužine $200 \mathrm{~mm}$, a svjetlost osiguravaju bijele led lampice visoke snage (Slika 4).

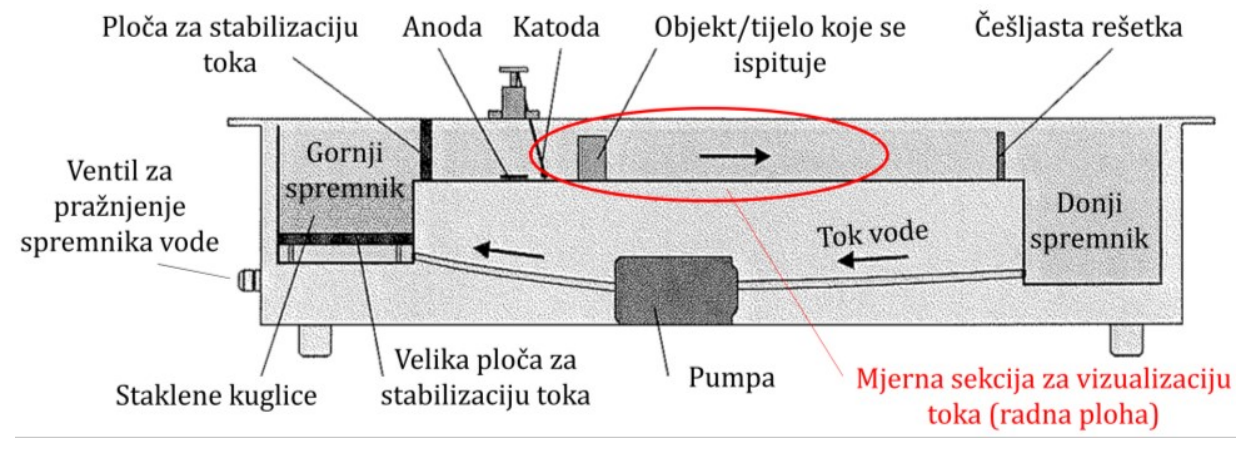

Slika 3. Fizikalni model HM 133 (bokocrt) [7] 
Tehničke karakteristike fizikalnog modela su sljedeće: maksimalni protok pumpe $Q=20 \mathrm{l} / \mathrm{min}$., generator mjehurića (struja: 0-200 $\mathrm{mA}$, pauza 8,4-1800 ms, impuls 8,4-1800 ms, 3 katodne žice od platine promjera 0,2 $\mathrm{mm}$, duljine 30, 50 i $75 \mathrm{~mm}$ te volumen vode za rad na modelu koji iznosi oko 6 litara (poželjno je da fizikalni model bude dobro ispunjen vodom kako ne bi došlo do moguće pojave uvlačenja zraka kroz usisnu cijev pri radu pumpe).

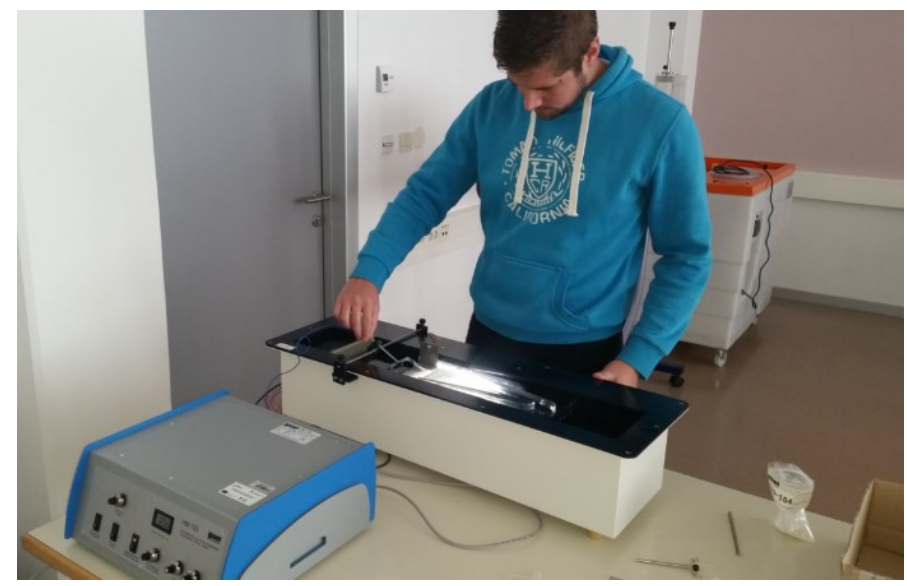

Slika 4. Rad na fizikalnom modelu HM 133 (Foto: Mauro Pamić)

\subsection{Fizikalni model HM 152}

Količina vode koja teče kroz područje između staklenih ploča može se kontrolirati preko dovodnog ventila. Voda koja se akumulira u gornjem spremniku potiskuje se kroz protočnu ploču (radnu sekciju, radnu ploču), dolazi u donji spremnik vode i konačno završava u posudi za pražnjenje [8] (Slika 5 i 6). Putem odvodne cijevi omogućeno je pražnjenje fizikalnog modela. Medij (najčešće plava tinktura) se sa područja punjenja kroz spojnu i distribucijsku cijev dalje vodi do 19 mlaznica (11 injekcijskih cjevčica za generiranje strujnica i 8 mlaznica za generiranje/formiranje izvora ili ponora) koje upuštaju tinkturu u radnu ploču na kojoj se promatra opstrujavanje fluida oko danog ravninskog tijela. Fizikalni model HM 152 omogućuje ispitivaču da prema potrebi ispita opstrujavanje fluida oko tijela bilo kojeg hidrodinamičkog oblika, što ovaj model čini veoma korisnim (Slika 6). Proizvoljni oblici tijela za koje se želi napraviti analiza opstrujavanja fluidom na danom modelu vrlo se jednostavno mogu izraditi (isprintati) na 3D printeru koji se nalazi u hidrotehničkom laboratoriju Građevinskog fakulteta Sveučilišta u Rijeci. Tehničke karakteristike fizikalnog modela su: dvije staklene ploče dimenzija $D$ x $\breve{S}=910 \times 585 \mathrm{~mm}$ na razmaku od $5 \mathrm{~mm}, 8$ spojeva (izvor/ponor), spremnik za boju od $200 \mathrm{ml}$, 
dok su ukupne dimenzije fizikalnog modela $D \times \check{x}$ x $V=1350 \times 700 \times 1380 \mathrm{~mm}$, a količina vode potrebna za rad iznosi oko $300 \mathrm{l} / \mathrm{h}$.

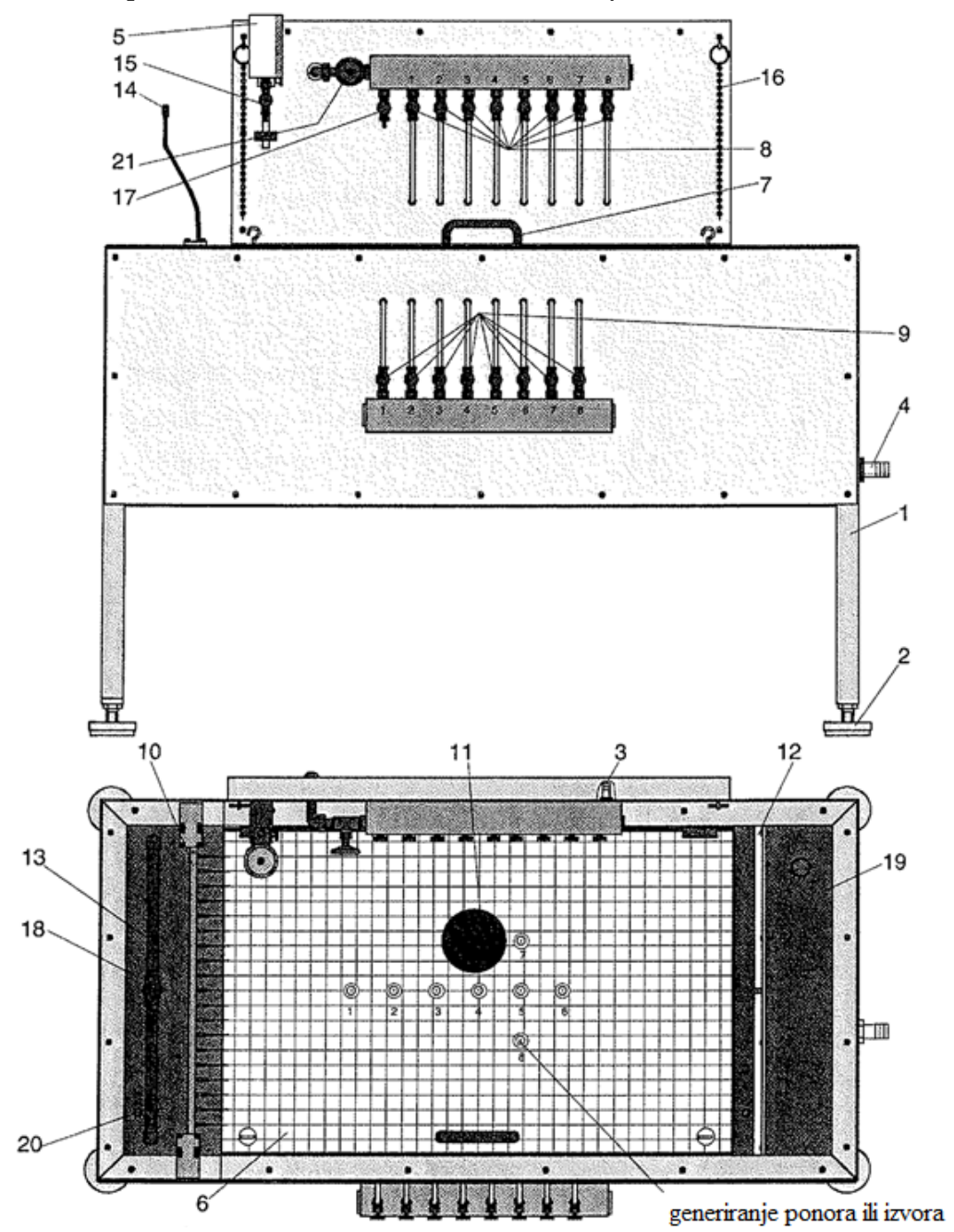

Slika 5. Osnovni elementi fizikalnog modela HM 152 [8]

1- nožica, 2 - stabilizatori postolja modela, 3 - dovod vode, 4 - odvod vode,

5 - spremnik za tinkturu, 6 - radna sekcija, 7 - držač staklene plohe,

8 - ventili za formiranje izvora ili ponora na radnoj sekciji, 9 - ventili za reguliranje dotoka tinkture, 10 - distribucijska cijev za dovod vode (gornji spremnik), 11 - tijelo koje se analizira, 12 - pregrada za stabilizaciju toka, 13 - gornji spremnik vode,

14 - konekcijsko crijevo za distribucijsku cijev, 15 - ventil za reguliranje dovoda tinkture, 16 - lanac za osiguranje (pridržavanje) staklene plohe, 17 - ventil za čiščenje injekcijskih mlaznica, 18 perforirana cijev za dovod vode, 19 - donji spremnik vode, 20 - ventil za reguliranje dotoka vode, 21 - ventil za reguliranje dovoda tinkture 


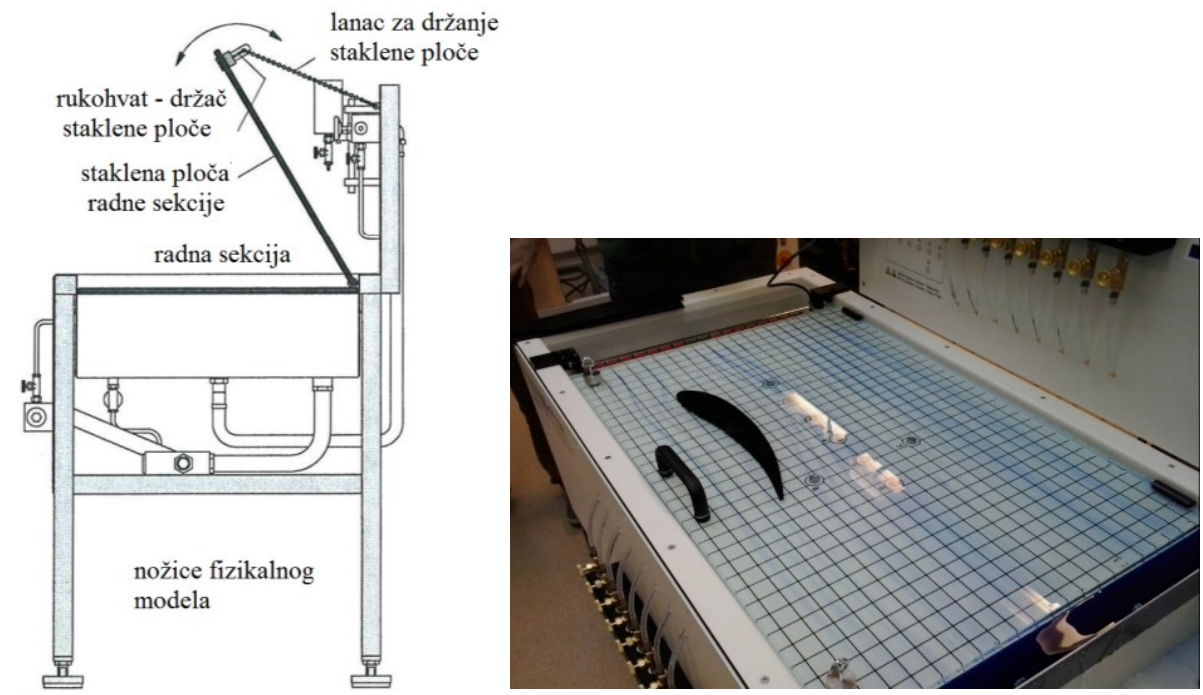

Slika 6. Fizikalni model HM 152 (lijevo) i aerofilno tijelo koje se ispituje (desno)

\section{Provedba i analiza fizikalnih ispitivanja}

\subsection{Fizikalni model HM 133}

PRIMJER 1 - opstrujavanje fluida oko cilindričnog hidrotehničkog tijela

Uslijed nailaska toka na cilindrično tijelo dolazi do deformiranja strujnica i stvaranja graničnog sloja uz samo tijelo (Slika 7.a). S obzirom da je tijelo cilindričnog oblika, i s jedne i druge strane presjeka postoji simetrično odvajanje graničnog sloja u smjeru toka.
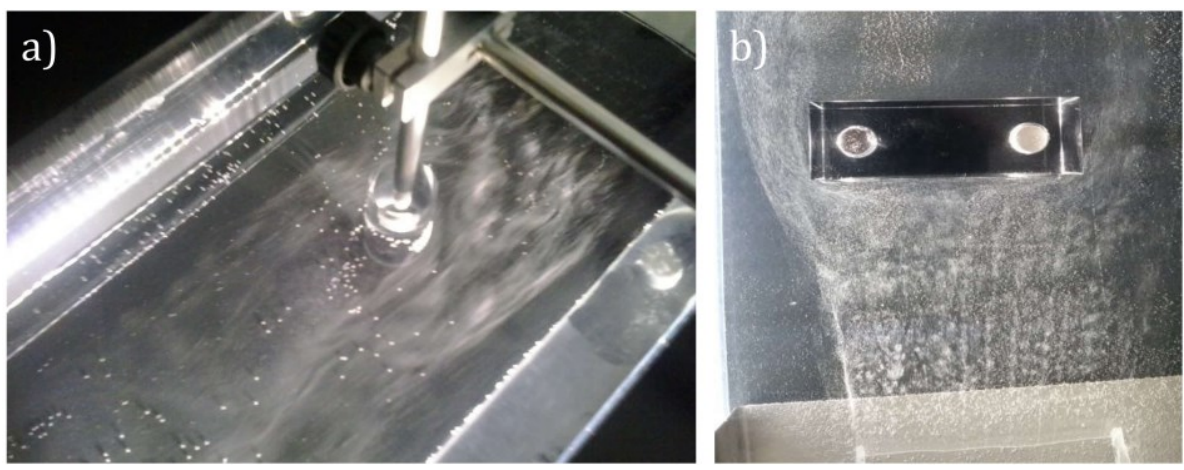

Slika 7. a) Opstrujavanje fluida oko cilindričnog hidrotehničkog tijela - PRIMJER 1.b) opstrujavanje fluida oko hidrotehničkog tijela pravokutnog oblika - PRIMJER 2 [6] 
Točke separacije se nalaze na mjestima koja su dulja od polovine promjera kružnog presjeka. Uslijed takvoga odvajanja, neposredno iza tijela formiraju se blagi vrtlozi. Budući da brzina strujanja nije toliko intenzivna, na kojih 20 -tak cm iza tijela strujnice se uravnotežuju te tok postaje stabilan (gotovo laminaran).

PRIMJER 2 - Opstrujavanje fluida oko tijela pravokutnog oblika

Kao što je vidljivo iz slike 7.b, nailaskom toka fluida na izduženo tijelo postavljeno okomito na tok dolazi do dolazi do formiranja graničnog sloja na bočnim rubovima zbog značajnih otpora samog tijela. Naime, tijelo se blago opstrujava (s vrlo blagim formiranjem vrtloga), jer svojom formom uvjetuje odvajanje graničnog sloja već na rubovima. Točke odvajanja (separacije) se na obje strane nalaze u vrhovima tijela. Odvajanje uzrokuje i nastanak blagih vrtloga te deformaciju strujnica u nizvodnom toku.

PRIMJER 3 - Opstrujavanje fluida oko zaobljenog pločastog tijela

Ovako položeno zaobljeno pločasto tijelo daje specifičnu sliku toka i podosta drugačije strujanje u odnosu na prethodna dva primjera (Slika 8). Naime, dok se na jednoj strani formira granični sloj duž cijele zakrivljene pločice i točka separacije nije vidljiva, na drugoj se pak strani granični sloj odvaja već na samom početku nailaska toka. Budući da je debljina pločice vrlo mala, za posljedicu će imati intenzivno stvaranje vrtloga.

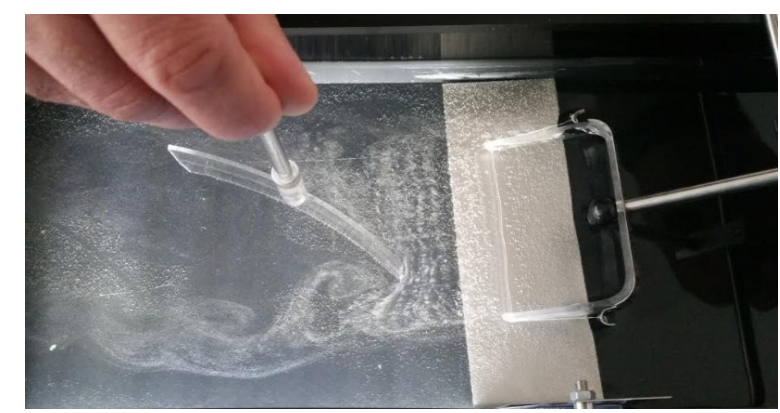

Slika 8. Opstrujavanje fluida oko zaobljenog tijela - PRIMJER 3 [6]

\subsection{Fizikalni model HM 152}

PRIMJER 1. - Opstrujavanje fluida oko aerofilnog tijela i izvora

Upuštanjem medija (tinkture) u gornju ploču fizikalnog modela dobiva se vrlo jasna slika promjene strujnog polja nailaskom fluida na aerofilni model (Slika 9.a). Na aerofilnom 2D tijelu se s obje strane formira granični sloj. Dok je s jedne strane on vrlo uzak i praktički priljubljen uz tijelo, s druge je strane on pomalo odmaknut. Zanimljivo je napomenuti kako između 2D 
tijela i izvora dolazi do sužavanja razmaka strujnica, što ukazuje na to da izvor uslijed nailaska strujnog toka također biva opstrujavan i da tok ne utječe na njegovu postojanost [6].
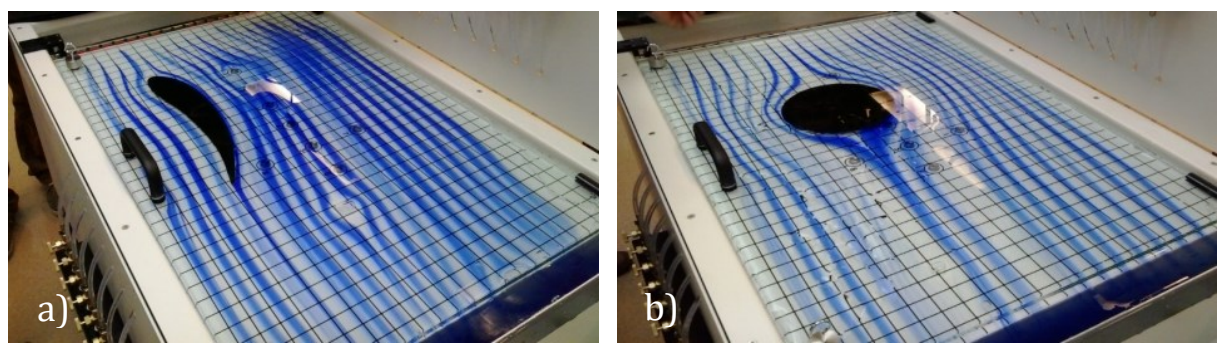

Slika 9. a) Opstrujavanje fluida oko aerofilnog tijela i izvora - PRIMJER 1, b) opstrujavanje fluida oko kružnog ravninskog tijela - PRIMJER 2 (Foto: Mauro Pamić) [6]

PRIMJER 2 - Opstrujavanje fluida oko kružnog ravninskog tijela

Ono što je karakteristično kod opstrujavanja fluida oko ovakvih tijela je to da po cijeloj širini toka dolazi do pojave simetričnog deformiranja strujnica (simetrična strujna slika u odnosu na poprečni presjek tijela). Za vrlo sporo tečenje granični sloj se formira iza samog promjera poprečnog presjeka tijela (nizvodniji dio kruga), a nakon njegova odvajanja se iza tijela formira gotovo stabilizirajući snop strujnica (strujnice su gotovo paralelne), kako je vidljivo na slici 9.b).

\section{Zaključak}

Problematika ovog rada fokusirana je na formiranje graničnog sloja te na ispitivanja putem fizikalnih modela HM 133 i HM 152. Graničnim slojem smatra se prostorni dio fluida koji teče neposredno uz podlogu ili u ovom slučaju neposredno uz razna uronjena geometrijska tijela, na kojem dolazi do odvajanja, tj. javlja se tzv. točka separacije. U ovom su se radu analizirala eksperimentalna ispitivanja pojave graničnog sloja kao posljedica opstrujavanja geometrijskih i prostorno različitih 2D i 3D tijela (kružnog, pravokutnog i aerofilnog oblika). Cilj ovih ispitivanja bio je dobiti jasnu strujnu sliku pri opstrujavanju fluida oko tijela opisanih oblika.

Pokazalo se da su korišteni fizikalni modeli dobri za provođenje ispitivanja jer ispitivaču daju mogućnost zornog doživljaja pojave te promatranja opstrujavanja fluida oko različitih oblika tijela, kako ravninskih tako i prostornih. To jasno ukazuje na vrijednost ovih fizikalnih modela za edukacijske i druge svrhe Građevinskog fakulteta u Rijeci.

Dobivena saznanja i hidrauličke analize temeljene na fizikalnim modelima moguće je usporediti sa numeričkim modelima koji se dotiču iste 
problematike. Dokazala je to provedena i u radu predstavljena analiza, ali može se ukazati i na daljnje mogućnosti. Tako je, na primjer, kod izvora i ponora na fizikalnom modelu HM 152, s obzirom na intenzitet izviranja ili poniranja, moguće dobiti jasan prikaz brzine širenja npr. oblaka zagađenja, brzinu tečenja onečišćene vode kroz prostor te kakav je njezin utjecaj na daljnji tok. Također, za potrebe izgradnje lukobrana ili pera na riječnim tokovima, primjenom fizikalnog modela HM 133, za tijelo istog poprečnog presjeka kao lukobran vrlo se dobro mogu predvidjeti refrakcija i difrakcija valova, kao i mogući otpori pri tečenju. Konačno i konkretno, u nekom sljedećem radu, za odabrane hidrauličke oblike tijela može se putem PIV tehnologije (engl. Particle Image Velocimetry) izvršiti vizualizacija i hidraulička analiza opstrujavanja fluidom radi dobivanja jasnije slike 2D ili 3D polja vektora brzina.

Zahvala. Članak je rezultat rada u okviru projekta „Razvoj istraživačke infrastrukture na Kampusu Sveučilišta u Rijeci (RC.2.2.06-0001)“, koji sufinanciraju Europski fond za regionalni razvoj (EFRR) i Ministarstvu znanosti, obrazovanja i sporta Republike Hrvatske. Rad se također sufinancira iz istraživačke potpore Sveučilišta u Rijeci pod nazivom „Hidrologija vodnih resursa i identifikacija rizika od poplava i blatnih tokova na krškom području“.

\section{Literatura}

[1] Lončar, G., Andročec, V. (2010) Mehanika tekućina, skripta predavanja iz kolegija Mehanika fluida, Građevinski fakultet Sveučilišta u Zagrebu, Zagreb.

[2] Žic, E. (2017) Kinematika fluida, predavanja iz kolegija Hidromehanika, Građevinski fakultet Sveučilišta u Rijeci, Rijeka.

[3] Jović, V. (2006) Osnove hidrotehnike, Fakultet građevinarstva, arhitekture i geodezije, Sveučilište u Splitu, Split, Element.

[4] Bukurov, M., Žic, E. (2017) Dinamika viskoznog fluida, iz priručnika MEHANIKA FLUIDA - teoretske osnove, radni priručnik za potrebe studenata na kolegiju Mehanika fluida i Hidromehanika, Građevinski fakultet Sveučilišta u Rijeci, Rijeka.

[5] Pamić, M. (2017) Fizikalni model formiranja graničnog sloja, Završni rad iz kolegija Hidromehanika, Građevinski fakultet Sveučilišta u Rijeci, Rijeka.

[6] Žic, E., Ožanić, N., Karleuša, B. (2012) Mehanika fluida - teoretske osnove $s$ riješenim zadacima, Skripta zadataka iz kolegija hidromehanika, Građevinski fakultet Sveučilišta u Rijeci, Rijeka.

[7] Gunt HM 133. (2011) Visualisation of Flow Fields, priručnik za rad s fizikalnim modelom HM 133, Hamburg, Gunt Hamburg Ltd.

[8] Gunt HM 152. (1999) Flow Visualisation Table, priručnik za rad s fizikalnim modelom HM 152, Hamburg, Gunt Hamburg Ltd. 